\title{
Protein Folding and Misfolding: Deciphering Mechanisms of Age-Related Diseases
}

\author{
Judith-Elisabeth Riemer, Diana Panfilova, Heidi Olzscha
}

\section{CONTENTS}

2.1 Introduction / 13

2.1.1 Kinetic and Thermodynamic Aspects of Protein Folding / 13

2.2 Molecular Chaperones / 15

2.2.1 Definition of the Term Molecular Chaperone / 15

2.2.2 Significance of Molecular Chaperones in the Cell / 15

2.2.3 A Network of Molecular Chaperones / 16

2.2.4 Functions of Molecular Chaperones and Interplay with Other Protein Quality Control Systems / 17

2.3 Protein Misfolding / 18

2.3.1 Process of Protein Misfolding / 18

2.3.1.1 Amyloid Proteins / 18

2.3.2 Factors Leading to Protein Misfolding / 18

2.3.2.1 Mutations / 18

2.3.2.2 Nongenetic Causes / 18

2.4 Age-Related Proteinopathies / 20

2.4.1 Systemic Proteinopathies / 20

2.4.2 Localized Proteinopathies / 22

2.4.2.1 Non-nervous System-Related Diseases / 22

2.4.2.2 Nervous System-Related Diseases / 23

2.5 Current and Future Treatments / 24

2.6 Conclusions / 25

Author Contributions / 26

Funding / 26

Acknowledgment / 26

Conflicts of Interest / 26

References / 26

\subsection{INTRODUCTION}

\subsubsection{Kinetic and Thermodynamic Aspects of Protein Folding}

Protein folding refers to the physical process by which a protein obtains its native state and becomes functionally active. As correct protein folding is a prerequisite for proteostasis in biological systems, determining the mechanisms of this process is crucial for understanding agerelated diseases, especially proteinopathies, which are also named proteopathies or protein-folding diseases. A breakthrough in determining threedimensional structures of proteins occurred in 


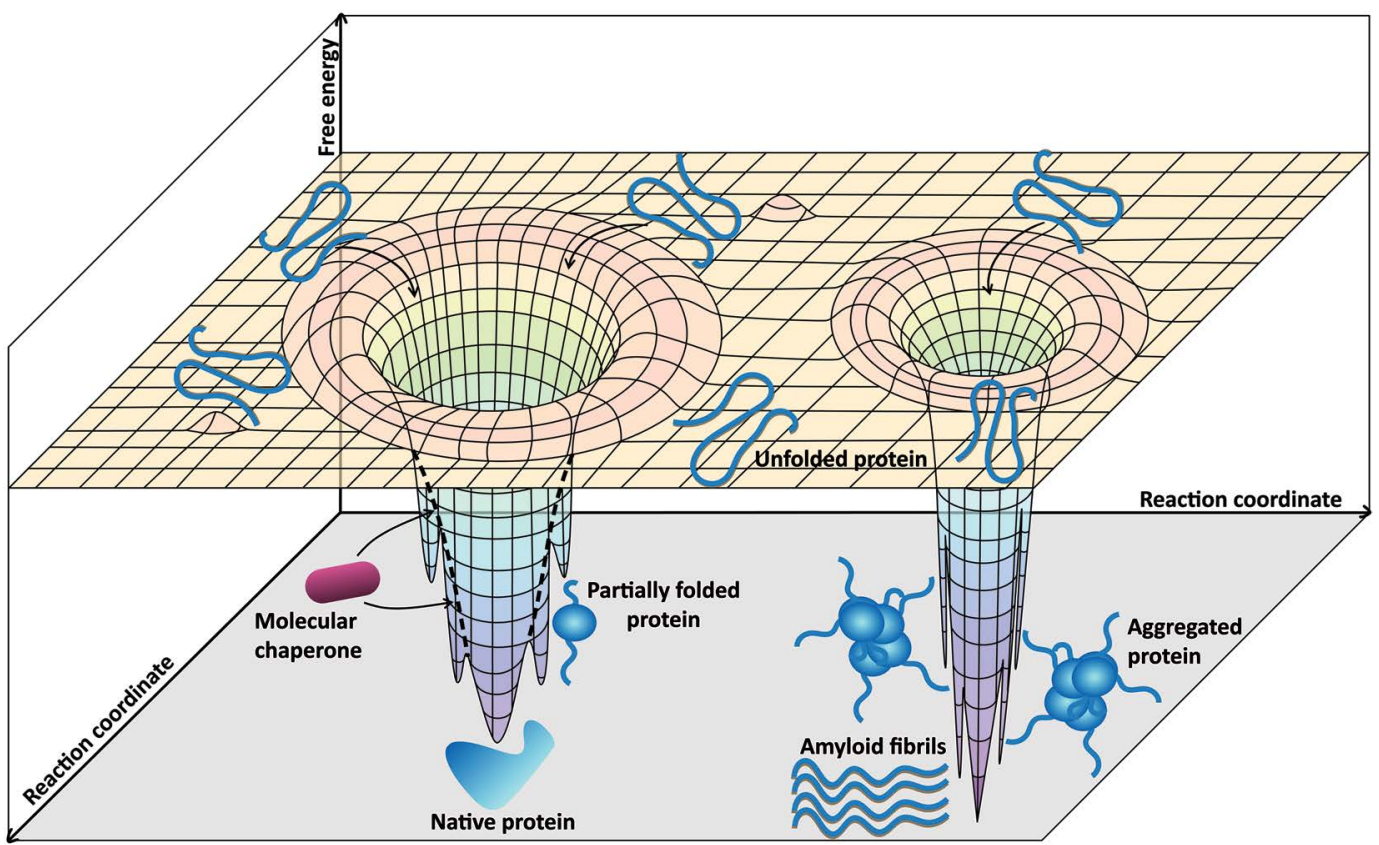

Figure 2.1 Protein-folding and misfolding energy landscape. During protein folding, unfolded proteins may have to surpass high free energy stages in order to "fall" into the folding funnel and reach their native conformation, thereby minimizing their free energy level. Molecular chaperones help to prevent trapping of partially folded proteins in low energy states. In case of protein misfolding, aggregated proteins can reach low free energy states and even form highly stable amyloid fibrils with minimal free energy levels.

the 1940s and 1950s, when Kendrew et al. (1958) and Pauling et al. (1951) discovered elements of secondary, tertiary and quaternary protein structures. Then, Anfinsen et al. (1961) demonstrated in 1961 for the small protein ribonuclease A that the information for its folding is inherent in its primary sequence. Another important theorem was given by Levinthal with the "Levinthal's paradox", which states that a protein has an astronomical number of possible conformations due to the high number of degrees of freedom in its chain (Levinthal, 1969). However, according to biophysical measurements, some small simple proteins can be folded in their active form in less than $50 \mu$ s, although the number of their possible conformations is extremely high (Mayor et al., 2003). This contradiction was explained by Anfinsen's thermodynamic hypothesis (Anfinsen's dogma) in 1973. It states that the unique native structure that is formed in the environment at which protein folding takes place is the most thermodynamically stable conformation (Anfinsen, 1973). Thus, according to Levinthal's and Anfinsen's hypothesis, many proteins are believed to self-assemble under thermodynamic control (Varela et al., 2019).
In general, the process of protein folding has two stages. Firstly, a molten globule is formed from the random coil of an unfolded protein, losing entropy with little change in energy. In the second, slower stage, the molten globule evolves into the native conformation with reduced free energy and only a small change in entropy (Shirdel and Khalifeh, 2019). These two stages combined form a "folding funnel" (Figure 2.1).

Before a protein reaches its native state, the protein folding goes through a stochastic search of conformations. In this process, the number of possible conformations is irrelevant. Of importance are the kinetically controlled conformations with distinct transition states. In other words, the kinetic control of folding events allows the existence of thermodynamically unstable molecular structures, which is called kinetic trapping (Dill, 1999). In order to prevent kinetic trapping of partially folded proteins, molecular chaperones assist in protein folding (Figure 2.1).

Although most proteins require a defined three-dimensional structure to fulfill their functions, there are some functional proteins in cells that can be either fully unstructured or have only 
TABLE 2.1

Frequently used methods to analyze protein folding.

\begin{tabular}{|c|c|c|}
\hline Methods & Physical principles & Output \\
\hline X-ray crystallography & $\begin{array}{l}\text { Scattering of X-ray waves through the } \\
\text { atoms' electrons of a protein crystal }\end{array}$ & $\begin{array}{l}\text { Three-dimensional electron density map of } \\
\text { electrons within a crystal. Gives } \\
\text { information about protein structure }\end{array}$ \\
\hline $\begin{array}{l}\text { Nuclear magnetic resonance } \\
\text { spectroscopy }\end{array}$ & $\begin{array}{l}\text { Atomic nuclei respond to oscillating } \\
\text { magnetic fields depending on the } \\
\text { local molecular environment }\end{array}$ & $\begin{array}{l}\text { A map of chemical bonds between the } \\
\text { protein's atoms and their relative position } \\
\text { in three-dimensional protein structure }\end{array}$ \\
\hline Cryo-electron microscopy & $\begin{array}{l}\text { A beam of electrons is transmitted } \\
\text { through a sample cooled to } \\
\text { cryogenic temperature }\end{array}$ & $\begin{array}{l}\text { Thousands of pictures taken from various } \\
\text { perspectives are combined to form a 3D } \\
\text { model }\end{array}$ \\
\hline Small-angle X-ray scattering & $\begin{array}{l}\text { Scattering of a monochromatic X-ray } \\
\text { beam through the structures with } \\
1-100 \mathrm{~nm} \text { dimensions }\end{array}$ & $\begin{array}{l}\text { Function of electron density distribution } \\
\text { within a protein. Gives information about } \\
\text { protein shape and size }\end{array}$ \\
\hline Circular dichroism & $\begin{array}{l}\text { Different absorption of left and right } \\
\text { circular polarized light through the } \\
\text { chiral systems like proteins }\end{array}$ & $\begin{array}{l}\text { Circular dichroism spectrum that is unique } \\
\text { for each conformation of a single protein }\end{array}$ \\
\hline Dynamic light scattering & $\begin{array}{l}\text { Light scattering through particles like } \\
\text { protein molecules }\end{array}$ & $\begin{array}{l}\text { Information about protein size. Changes in } \\
\text { molecular size of proteins during } \\
\text { folding/unfolding can be observed }\end{array}$ \\
\hline Fluorescence spectroscopy & $\begin{array}{l}\text { Aromatic amino acids like Trp and Tyr } \\
\text { emit light that is absorbed, while } \\
\text { emission peaks depend on the } \\
\text { polarity of the local environment }\end{array}$ & $\begin{array}{l}\text { A fluorescence spectrum gives information } \\
\text { about protein-folding state and } \\
\text { conformation }\end{array}$ \\
\hline
\end{tabular}

unstructured regions; they are termed intrinsically disordered proteins (IDP) and intrinsically disordered regions (IDR), respectively (Dyson and Wright, 2005). Notably, many proteins involved in proteinopathies contain IDRs, including $A \beta$, $\alpha$-synuclein and the pathologic form of prion proteins ( $\mathrm{PrP}^{\mathrm{sc}}$ ) (Knowles et al., 2014).

A variety of methods exists that allows to study protein folding and misfolding as summarized in Table 2.1.

\subsection{MOLECULAR CHAPERONES}

\subsubsection{Definition of the Term Molecular Chaperone}

Molecular chaperones can be defined as proteins occurring in all taxonomic domains of life that assist other cellular proteins (clients) to adopt their final physiologically active form without being part of their functional structure (Hartl, 1996). Molecular chaperones should be distinguished from chemical chaperones, which are small physiological or non-natural molecules including osmolytes and hydrophobic compounds that can enhance protein stability and folding (Ignatova and Gierasch, 2006). Molecular chaperones do not have a built-in-concept of their clients resembling a catalytic center, which discriminates them from folding catalysts. They are enzymes such as peptidyl-prolyl-isomerases or protein disulfide isomerases, which can break and build covalent bonds (Wang et al., 2015).

\subsubsection{Significance of Molecular Chaperones in the Cell}

Most molecular chaperones can be upregulated and activated by cells in response to stressful conditions including abnormal temperature and redox states, whereas some molecular chaperones are constitutively expressed. Many, but not all heat shock proteins (Hsp), are molecular chaperones, and vice versa many, but not all molecular chaperones, are Hsps (Nollen and Morimoto, 2002). Constitutively expressed molecular chaperones are often abbreviated as Hsc (heat shock cognate proteins). Compared to a simple folding experiment with a single protein in a test tube (Anfinsen 
TABLE 2.2

Major molecular chaperone families, their structural characteristics and selected functions.

\begin{tabular}{|c|c|c|c|c|c|}
\hline $\begin{array}{l}\text { Molecular } \\
\text { chaperone } \\
\text { family }\end{array}$ & $\begin{array}{l}\text { Examples } \\
\text { prokaryotes }\end{array}$ & $\begin{array}{l}\text { Examples } \\
\text { humans }\end{array}$ & $\begin{array}{l}\text { Nomenclature } \\
\text { for human } \\
\text { genes }\end{array}$ & $\begin{array}{l}\text { Oligomerization } \\
\text { degree }\end{array}$ & Selected functions \\
\hline Hsp1 10 & - & Hsp1 10 & $\mathrm{HSPH}$ & $\begin{array}{l}\text { Monomer } \\
\quad \text { (interacting } \\
\text { with Hsp70) }\end{array}$ & $\begin{array}{l}\text { Recognition of unfolded proteins; } \\
\text { nucleotide exchange factors (NEF) } \\
\text { for Hsp70 }\end{array}$ \\
\hline Hsp100 & Clp family & Hsp104 & - & 6-/7-mer & $\begin{array}{l}\text { Folding of newly synthesized proteins, } \\
\text { disaggregation of aggregated } \\
\text { proteins; stress tolerance }\end{array}$ \\
\hline Hsp90 & HtpG & Hsp90 & HSPC & Dimer & $\begin{array}{l}\text { Regulation of HSR; signal } \\
\text { transduction, e.g. transport of } \\
\text { hormone receptors; stabilizing } \\
\text { proteins }\end{array}$ \\
\hline Hsp70 & DnaK & $\begin{array}{l}\text { Hsp70, } \\
\text { Hsc70 }\end{array}$ & HSPA & $\begin{array}{l}\text { Monomer } \\
\text { (interacting } \\
\text { with Hsp40 } \\
\text { and Hsp1 10) }\end{array}$ & $\begin{array}{l}\text { Binding and folding of nascent chains } \\
\text { and unfolded proteins; protein } \\
\text { transport; refolding of proteins; heat } \\
\text { shock regulation }\end{array}$ \\
\hline $\begin{array}{l}\text { Chaperonins } \\
\text { (Hsp60) }\end{array}$ & GroEL/ES & $\begin{array}{l}\text { Hsp60, } \\
\text { TRiC/CCT }\end{array}$ & HSPE & 14-/16-mer & $\begin{array}{l}\text { Folding of non-nascent proteins; } \\
\text { specialized in their substrates, e.g. } \\
\text { TRiC/CCT with actin and tubulin }\end{array}$ \\
\hline Hsp40 & DnaJ & Hsp40, Hdj & DNAJ & $\begin{array}{l}\text { Monomer } \\
\quad \text { (interacting } \\
\text { with Hsp70) }\end{array}$ & $\begin{array}{l}\text { Substrate holding (holdase); essential } \\
\text { co-factor for the ATP-dependent } \\
\text { Hsp70 chaperones }\end{array}$ \\
\hline Small Hsps & Ipb, Hsp20 & $\begin{array}{l}\text { Hsp25, } \\
\text { Hsp27 }\end{array}$ & HSPB & 8 - to 24 -mer & $\begin{array}{l}\text { Protein folding; preventing misfolding } \\
\text { and aggregation; microfilament } \\
\text { stabilization }\end{array}$ \\
\hline
\end{tabular}

et al., 1961), folding of proteins in cells is much more complex making the presence of molecular chaperones inevitable. Firstly, protein folding occurs in a crowded environment, leading to an excluded volume effect. This stems from the fact that macromolecules occupy a large proportion of the available volume in the cell, which reduces the volume of solvent that is available for protein folding. As a result, proteins have fewer degrees of freedom for folding (Ellis, 2001). Secondly, the protein emerges slowly from the ribosome tunnel during translation, and exposed hydrophobic patches may interact with each other intra- or intermolecularly (Etchells and Hartl, 2004). Molecular chaperones protect these exposed regions and prevent misfolding and tagging for degradation. Thirdly, the proteome, especially in eukaryotic cells, is diverse and needs different folding microenvironments, to assist different classes of proteins in folding (Kerner et al., 2005). Especially chaperonins, that are large cylindrical molecular machines, can discharge the clients into their cavity and facilitate folding.

\subsubsection{A Network of Molecular Chaperones}

Molecular chaperones are grouped into families and named according to their molecular weight (Table 2.2). To ensure that the folding of the proteome in its entirety is covered and the flux through the network of molecular chaperones is maintained, protein folding is often organized in folding pathways. It is therefore widely accepted that one molecular chaperone can hand over its clients to the next molecular chaperone, sometimes belonging to a different family (Figure 2.2). Some molecular chaperone systems are ATPdependent, including Hsp60, Hsp70 and Hsp90. Chaperonins belong to the Hsp60 family and they are special in that they provide a protected environment as a nanocage for ATP-assisted folding cycles (Hayer-Hartl et al., 2016). Members of 


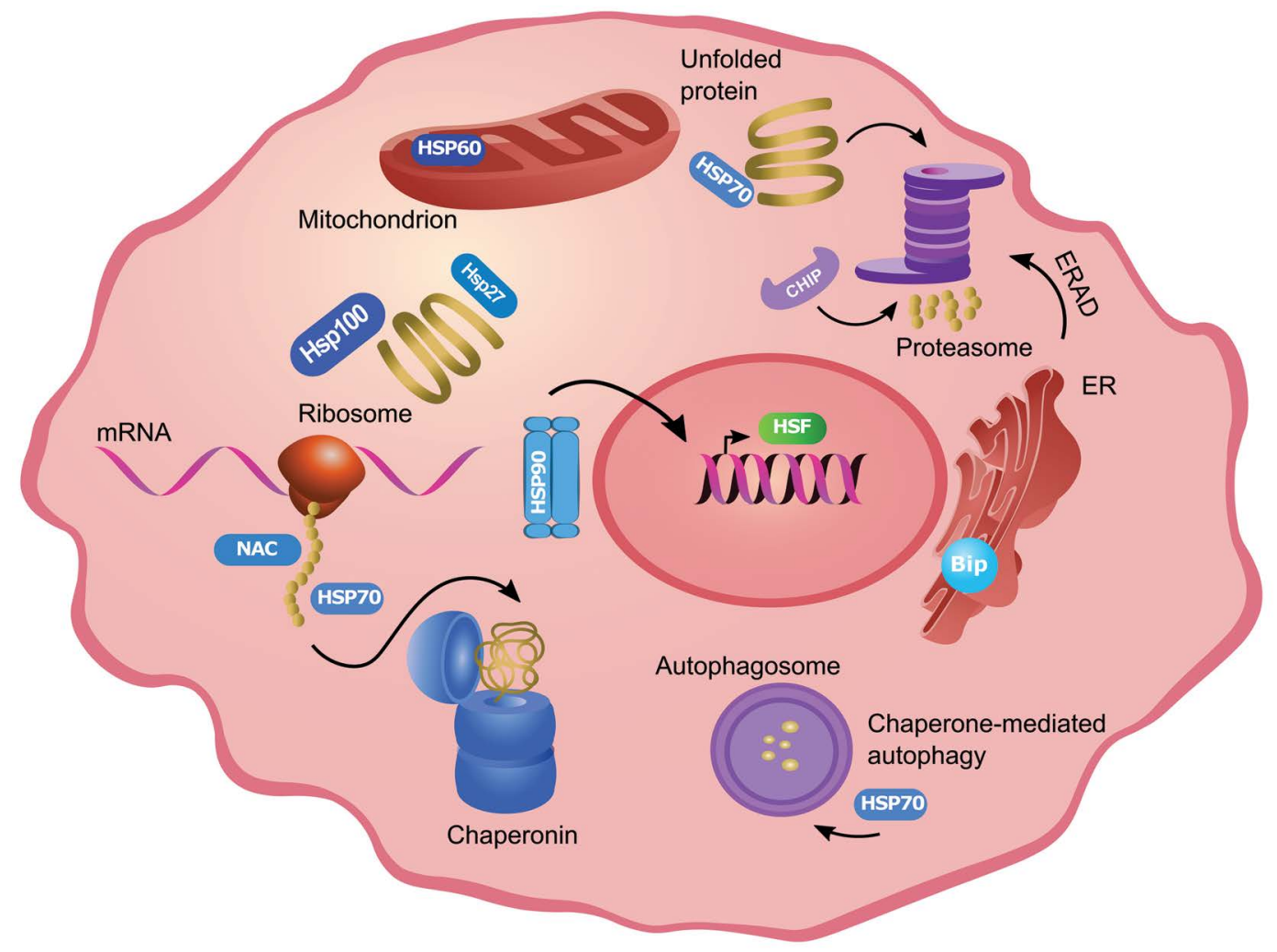

Figure 2.2 The network of molecular chaperones. The figure displays a network of the major molecular chaperone families in a eukaryotic cell and interactions with other protein quality control (PQC) systems. Molecular chaperones are depicted in blue, nucleic acids in magenta, protein chains in yellow, transcription factors in green and biomolecular degradation systems in purple.

other Hsp families can simply bind and stabilize the client in an ATP-independent manner such as Hsp40 and some of the small Hsps. The respective chaperones are sometimes termed foldases or holdases, respectively. The concerted action of the molecular chaperones needs to be tightly regulated with the help of heat shock factors (HSFs). HSFs are transcription factors that are bound by molecular chaperones, which can be released upon cellular stress, bind onto special regions of the genome called heat shock response elements (HSE) and initiate the transcription of stress response genes (Sarge et al., 1993).

\subsubsection{Functions of Molecular Chaperones and Interplay with Other Protein Quality Control Systems}

Aside from assisting in co-translational and posttranslational de novo protein folding, molecular chaperones can refold misfolded proteins and destroy protein aggregates (Nillegoda et al., 2015). Molecular chaperones do not act only in the cytoplasm; they are important proteostatic factors in the nucleus, endoplasmic reticulum (ER), mitochondria and chloroplasts, where they are also involved in protein transport.

A stress response similar to the heat shock response in the cytoplasm can occur in the ER. The cell handles misfolded proteins in the ER by initiating an unfolded protein response (UPR), where ER-residing chaperones such as Bip (binding immunoglobulin $[\mathrm{Ig}]$ protein) help with protein folding but also retrograde transport through the ER membrane (Walter and Ron, 2011). This is tightly coupled with the ER-associated protein degradation (ERAD) (Christianson et al., 2011). During ERAD, misfolded proteins are recognized and transported back into the cytoplasm, where they are handed over to the ubiquitin-proteasome system (UPS). Chaperones binding misfolded proteins in the cytoplasm can be recognized by 
adaptor proteins which label the protein with ubiquitin for degradation, like the E3 ligase CHIP (C-terminus of HSC70 interacting protein) (Smith et al., 2013). Some proteasomal shuttling factors belonging to the UbL/UbA (ubiquitinlike/ubiquitin-associated protein) family, such as HR23B, contain chaperone-binding domains and may interact with molecular chaperones (New et al., 2013). Molecular chaperones also play a role in targeting misfolded proteins for autophagy, especially for chaperone-mediated autophagy (CMA) (Kaushik and Cuervo, 2012).

\subsection{PROTEIN MISFOLDING}

As mentioned above, the free energy of a protein is determined by intramolecular interactions between amino acid residues. Thus, even small changes in the protein chain, for example due to mutations or aging, can cause reshaping of the folding funnel landscape, which may result in the formation of a new global free-energy minimum. This new stable state can initiate protein misfolding and therefore lead to different adverse effects including loss of protein function and aggregation (Clark, 2004).

\subsubsection{Process of Protein Misfolding}

Most proteins can fold from their native state toward misfolded species, crossing different intermediate states. However, misfolded species and aggregates can originate from both intermediate and native states of a protein (Clark, 2004) (Figure 2.3).

Due to the high-energy barrier that needs to be surpassed to obtain the native conformation, molecules can get trapped in partially folded states. These proteins might interact with other partially folded proteins and form aggregates, as they often expose hydrophobic amino acid residues and domains on their surface (Liu and Eisenberg, 2002). The process of aggregation is concentration-dependent, driven by hydrophobic forces and can result in amorphous or highly organized structures (Chiti and Dobson, 2006). Interestingly, some misfolded proteins are able to convert their native protein variants into misfolded proteins; these types of proteins are called prions (proteinaceous infectious particle derived from the words protein and infection) (Prusiner, 1982). Protein aggregation can also be caused by aberrant posttranslational modifications (PTM) including proteolytic cleavage, glycosylation, phosphorylation, ubiquitination or acetylation (Olzscha, 2019; Olzscha et al., 2017).

\subsubsection{Amyloid Proteins}

Protein aggregates can be more stable than native proteins due to the depth of the kinetic trap (Gregersen et al., 2006). Through nucleation processes, aggregates can initiate the formation of pre-amyloid oligomers, which can grow into protofilaments and eventually mature fibrils with cross- $\beta$-structures. These structures are characterized by a perpendicular arrangement of $\beta$-strands along the fibril axis. Once a certain size of a protein-consisting nucleus is reached ("critical nucleus"), aggregates grow exponentially, due to partial dissociation, providing an increasing number of seeds that repeatedly form new aggregates. In case of amyloid fibrils that are highly organized and stable structures, spontaneous dissociation into monomers is unlikely (Lashuel et al., 2002). Abnormal deposition of such amyloid structures in extracellular compartments can be observed in a wide group of diseases called amyloidoses (Benson et al., 2018).

\subsubsection{Factors Leading to Protein Misfolding}

\subsubsection{Mutations}

Genetic alterations can cause changes in protein structure, function or localization within the cell. Even minor modifications can make a protein prone to misfold or aggregate which leads to a number of inheritable diseases (Gámez et al., 2018) (Figure 2.4).

For example, a single nucleotide polymorphism can lead to the manifestation of cystic fibrosis $(\mathrm{CF})$, as demonstrated by the phenotypes associated with the $\triangle$ F508-CFTR (CF transmembrane conductance regulator protein)-mutated allele. This allele carries a deletion of a phenylalanine, leading to the misfolding of CFTR in the ER and its impaired trafficking toward the plasma membrane (Goor et al., 2006).

\subsubsection{Nongenetic Causes}

During aging, PQC systems begin to malfunction, which can lead to the accumulation of unfolded, misfolded and aggregated proteins. 


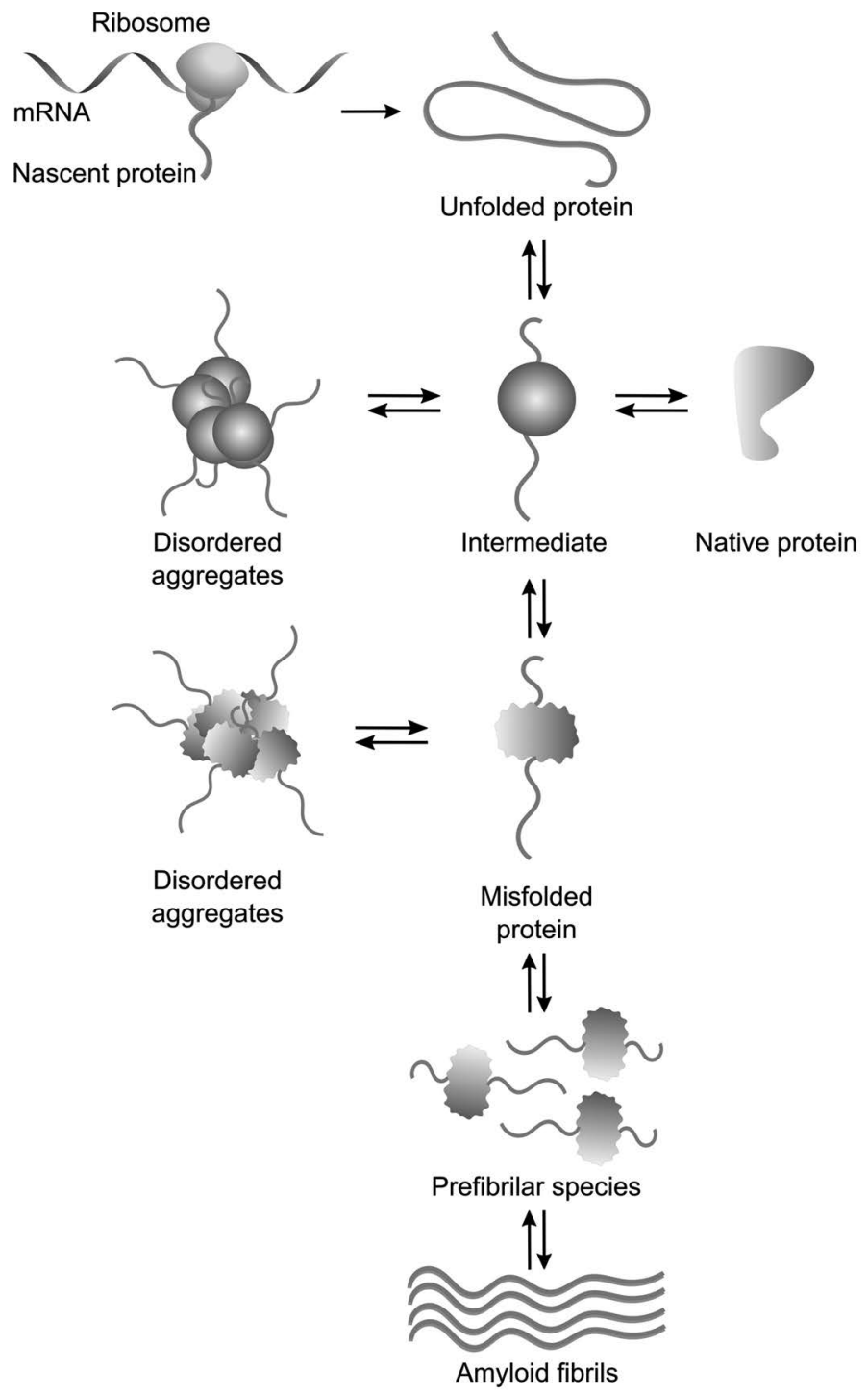

Figure 2.3 Protein folding and misfolding. Different steps in protein folding, misfolding and aggregation starting with the nascent polypeptide chain are displayed.

For instance, the heat shock response (HSR) becomes less sensitive with age, leading to slower and reduced activation of molecular chaperones (Calderwood et al., 2009). The increased amount of toxic protein species can then lead to cellular dysfunction, further impairment of the PQC systems and disease acceleration (Gidalevitz et al., 2006) (Figure 2.3).

Like aging and mutations, high levels of stress, including oxidative stress, can cause protein misfolding. High amounts of reactive oxygen species (ROS) in a cell can affect biomolecules and lead to lipid peroxidation as well as a range of different PTMs, which may make proteins prone to misfolding or aggregation (Levy et al., 2019). Aldehyde products resulting from lipid peroxidation such as 4-hydroxy-2-nonenal (HNE) can then further trigger formation of aberrant PTMs and this has been shown to give rise to toxic oligomeric species formed by the affected proteins (Xiang et al., 2015). Neurons in particular tend to be more vulnerable to oxidative stress than other cell types due to several reasons. Firstly, they are highly dependent on glucose oxidation as a major 


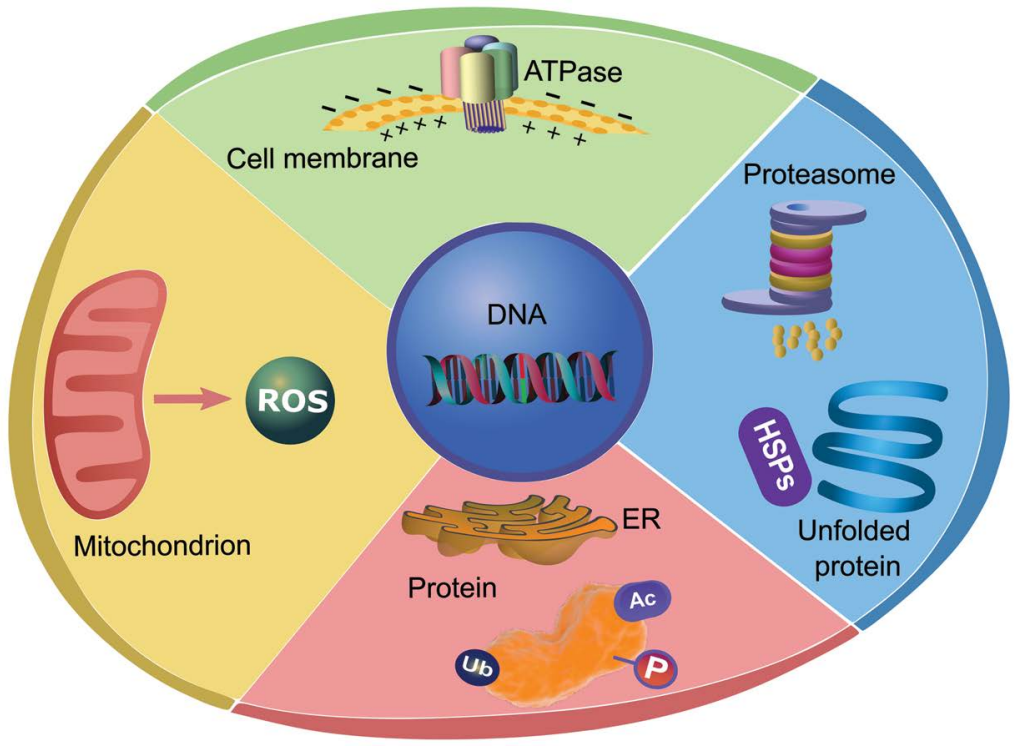

Figure 2.4 Factors leading to protein misfolding. There is a variety of factors affecting the protein-folding process and thus leading to misfolded protein species including mutations (dark blue section), chemiosmotic stress (green section), declining protein quality control (light blue section), aberrant posttranslational modifications (red section) and redox reactions (yellow section).

energy source. An imbalance in energy-producing processes, for example through aging mechanisms, can significantly affect redox homeostasis. Secondly, due to their post-mitotic state, neurons become more prone to the accumulation of ROS (Cobley et al., 2018). In Parkinson's disease (PD) for example, mitochondrial dysfunction and increase of intracellular ROS play a key role in pathogenesis (Schapira and Gegg, 2011) (Figure 2.4).

\subsection{AGE-RELATED PROTEINOPATHIES}

Misfolding and aggregation of proteins can cause cytotoxicity through many different pathways. Considering that these proteins do not reach their native conformation, they cannot execute their normal functions. This can lead to disturbances of cellular processes, cell death and can trigger disease onset.

Moreover, protein misfolding may have harmful effects based on the gain-of-function hypothesis of misfolded proteins. Research also suggests that oligomeric species that precede fibril formation in aggregation processes induce greater cytotoxic effects than mature fibrils and play a key role in driving neurodegeneration (Rockenstein et al., 2014). They characteristically expose hydrophobic domains, singular $\beta$-strands and IDRs on their surface, interacting with proteins of various functions, often IDRs themselves and involved in key cellular processes (Olzscha et al., 2011) (see Table 2.3).

\subsubsection{Systemic Proteinopathies}

Amyloidoses are diseases with various clinical manifestations in which amyloid structures accumulate in tissues. Proteinopathies and amyloidoses can be discriminated, based on their localization, in systemic and localized diseases. One example of a systemic form of amyloidosis is $\beta_{2}$-microglobulin amyloidosis $\left(A \beta_{2} M\right)$. High concentrations but also mutations of the protein (hereditary $\mathrm{A} \beta_{2} \mathrm{M}$-amyloidosis) can make it prone to misfolding and lead to consequent deposition in different connective tissues (Stoppini and Bellotti, 2015). Clinical signs are carpal-tunnel syndrome and other joint pains as well as bone cysts and consequent pathological fractures.

Multiple myeloma (MM) is a hematologic malignancy in which monoclonal plasma cells in the bone marrow produce high amounts of Igs uncontrollably. In the case of Bence-Jones protein (BJP)-MM, mostly Ig light chains accumulate, which can cause kidney damage (Umberto et al., 
TABLE 2.3

Selected array of age-related conformational diseases.

\begin{tabular}{|c|c|c|c|c|}
\hline Proteinopathy & Pathophysiology & $\begin{array}{l}\text { Aggregated/ } \\
\text { Misfolded protein }\end{array}$ & Age of onset & Clinical features \\
\hline \multicolumn{5}{|c|}{ I. Systemic } \\
\hline $\begin{array}{l}\text { Systemic } \\
\text { amyloidosis } \\
\left(\mathrm{A} \boldsymbol{\beta}_{2} \mathrm{M}\right)\end{array}$ & $\begin{array}{l}\text { Impaired renal clearance/ } \\
\text { dialysis therapy/ } \\
\text { misfolding mutations } \\
\text { cause accumulation of } \\
\mathrm{A} \beta_{2} \mathrm{M}\end{array}$ & $\beta_{2}$-Microglobulin & $\begin{array}{l}\text { Usually } \\
\text { following } \\
\text { chronic kidney } \\
\text { disease }\end{array}$ & $\begin{array}{l}\text { Arthralgia, bone cysts } \\
\text { and pathological } \\
\text { fractures }\end{array}$ \\
\hline $\begin{array}{l}\text { Amyloid } \\
\text { transthyretin } \\
\text { amyloidosis } \\
\text { (ATTR) }\end{array}$ & $\begin{array}{l}\text { TTR conversion into } \\
\text { amyloid fibrils } \\
\text { Familial amyloid } \\
\text { polyneuropathy (FAP): } \\
\text { Val30Met mutation } \\
\text { Familial amyloid } \\
\text { cardiomyopathy (FAC): } \\
\text { Val122IIe mutation } \\
\text { Wild-type ATTR amyloidosis } \\
\text { (ATTRwt): acquired } \\
\text { during aging }\end{array}$ & Transthyretin & $\begin{array}{l}50-60 \text { years } \\
\text { ATTRwt: }>60 \\
\quad \text { years }\end{array}$ & $\begin{array}{l}\text { FAP: polyneuropathy, } \\
\text { neurogenic } \\
\text { bladder, autonomic } \\
\text { dysfunction } \\
\text { FAC: arrhythmia, } \\
\text { heart failure } \\
\text { ATTRwt: } \\
\text { cardiological } \\
\text { manifestations, } \\
\text { arrhythmia, carpal } \\
\text { tunnel syndrome }\end{array}$ \\
\hline $\begin{array}{l}\text { Multiple myeloma } \\
\text { (MM) }\end{array}$ & $\begin{array}{l}\text { Malignant degeneration of } \\
\text { plasma cells, producing } \\
\text { high amounts of Ig/Ig } \\
\text { light chains }\end{array}$ & $\begin{array}{l}\text { Igs/Ig light chains } \\
\text { Bence Jones protein } \\
\text { (BJP) }\end{array}$ & 50-70 years & $\begin{array}{l}\text { B-symptomatology, } \\
\text { anemia, bone } \\
\text { pains, osteolysis }\end{array}$ \\
\hline
\end{tabular}

IIa. Localized (Non-nervous system related)

\begin{tabular}{|c|c|c|c|c|}
\hline $\begin{array}{l}\text { Primary localized } \\
\text { cutaneous } \\
\text { amyloidosis } \\
\text { (PLCA) }\end{array}$ & $\begin{array}{l}\text { Mutations in OSMR or } \\
\text { IL31RA, amyloid deposits } \\
\text { in skin, mechanisms } \\
\text { unknown }\end{array}$ & IL-3 1 receptor & Adulthood & $\begin{array}{l}\text { Pruritus, skin } \\
\text { scratching, } \\
\text { discolored skin }\end{array}$ \\
\hline Cataract & $\begin{array}{l}\text { Loss of transparency of eye } \\
\text { lens, aggregates form } \\
\text { through accumulation of } \\
\text { oxidative stress }\end{array}$ & $\gamma$-Crystalline & $>65$ years & $\begin{array}{l}\text { Blurred/Impaired } \\
\text { vision }\end{array}$ \\
\hline
\end{tabular}

IIb. Localized (nervous system related)

\begin{tabular}{|c|c|c|c|c|}
\hline $\begin{array}{l}\text { Alzheimer's disease } \\
\text { (AD) }\end{array}$ & $\begin{array}{l}\text { Inadequate clearance/ } \\
\text { increased production of } \\
\mathrm{A} \beta \text {, hyperphosphorylation } \\
\text { of tau }\end{array}$ & $\begin{array}{l}\mathrm{A} \beta \\
\text { Tau }\end{array}$ & $>65$ years & $\begin{array}{l}\text { Dementia, loss of } \\
\text { cognitive functions }\end{array}$ \\
\hline $\begin{array}{l}\text { Frontotemporal } \\
\text { dementia (FTD)/ } \\
\text { Frontotemporal } \\
\text { lobar } \\
\text { degeneration } \\
\text { (FTLD) }\end{array}$ & $\begin{array}{l}\text { FTLD-tau: astrocytic } \\
\text { plaques, corticobasal } \\
\text { degeneration, Pick bodies } \\
\text { FTLD-TDP: cytoplasmic } \\
\text { inclusions, dystrophic } \\
\text { neurites }\end{array}$ & $\begin{array}{l}\text { Tau } \\
\text { TDP-43 }\end{array}$ & $\begin{array}{l}\text { 45-64 years } \\
\text { "Early-onset } \\
\text { dementia” }\end{array}$ & $\begin{array}{l}\text { Dementia, prominent } \\
\text { behavioral features, } \\
\text { language deficit }\end{array}$ \\
\hline $\begin{array}{l}\text { Parkinson's disease } \\
\text { (PD) }\end{array}$ & $\begin{array}{l}\text { Degeneration of } \\
\text { dopaminergic neurons, } \\
\text { neuronal inclusions of } \\
\text { aggregated } \alpha \text {-synuclein }\end{array}$ & $\alpha$-Synuclein & $50-60$ years & $\begin{array}{l}\text { Bradykinesia, } \\
\text { muscular rigidity, } \\
\text { tremor }\end{array}$ \\
\hline
\end{tabular}




\begin{tabular}{|c|c|c|c|c|}
\hline Proteinopathy & Pathophysiology & $\begin{array}{l}\text { Aggregated/ } \\
\text { Misfolded protein }\end{array}$ & Age of onset & Clinical features \\
\hline $\begin{array}{l}\text { Lewy body dementia } \\
\text { (LBD) }\end{array}$ & $\begin{array}{l}\text { Majority sporadic, rare } \\
\text { mutations: SNCA, LRRK2 } \\
\text { gene. Neuronal inclusions } \\
\text { of } \alpha \text {-synuclein, with or } \\
\text { without A } \beta \\
\text { Cerebrovascular pathology }\end{array}$ & $\begin{array}{l}\alpha \text {-Synuclein } \\
\mathrm{A} \beta\end{array}$ & 65 years & $\begin{array}{l}\text { Dementia, deficit in } \\
\text { attention span, } \\
\text { executive function } \\
\text { Visual hallucinations, } \\
\text { spontaneous } \\
\text { parkinsonism }\end{array}$ \\
\hline $\begin{array}{l}\text { Multiple system } \\
\text { atrophy (MSA) }\end{array}$ & $\begin{array}{l}\text { Glial and neuronal } \\
\text { inclusions of } \alpha \text {-synuclein, } \\
\text { demyelination, gliosis }\end{array}$ & $\alpha$-Synuclein & $55-65$ years & $\begin{array}{l}\text { MSA-P } \\
\quad \text { (parkinsonian): } \\
\text { parkinsonism } \\
\text { MSA-C(cerebellar): } \\
\text { ataxia } \\
\text { Autonomic failure, } \\
\text { sleep disorders }\end{array}$ \\
\hline $\begin{array}{l}\text { Spinocerebellar } \\
\text { ataxia (SCA) }\end{array}$ & $\begin{array}{l}\text { PolyQ expansions in } \\
\text { different proteins, } \\
\text { aggregation in cerebellar } \\
\text { neurons }\end{array}$ & $\begin{array}{l}\text { Ataxin- } 1 / 2 / 3 / 7 \\
\text { TBP (TATA-binding } \\
\text { protein) } \\
\text { CACNA1A (calcium } \\
\text { channel) }\end{array}$ & $\begin{array}{l}\text { Adulthood } \\
\text { Depending on } \\
\text { SCA type }\end{array}$ & $\begin{array}{l}\text { Ataxia, neuronal } \\
\text { atrophy, specific } \\
\text { symptoms in } \\
\text { different SCA } \\
\text { forms }\end{array}$ \\
\hline $\begin{array}{l}\text { Huntington's disease } \\
\text { (HD) }\end{array}$ & $\begin{array}{l}\text { Mutation in IT-15 gene } \\
\text { PolyQ expansions and } \\
\text { aggregation of } \mathrm{Htt}\end{array}$ & Huntingtin (Htt) & $30-50$ years & $\begin{array}{l}\text { Abnormal motor } \\
\text { movements, } \\
\text { personality change }\end{array}$ \\
\hline Prion's disease & $\begin{array}{l}\text { Infectious proteinaceous } \\
\text { particles (prions) lead to } \\
\text { misfolding/aggregation } \\
\text { of other proteins }\end{array}$ & Prion protein & $\begin{array}{l}\text { Around } 60 \text { years } \\
\text { Latent onset } \\
\quad(20-30 \text { years } \\
\text { after infection) }\end{array}$ & $\begin{array}{l}\text { Psychopathological } \\
\text { abnormalities, } \\
\text { severe dementia, } \\
\text { myoclonus }\end{array}$ \\
\hline $\begin{array}{l}\text { Amyotrophic Lateral } \\
\text { Sclerosis (ALS) }\end{array}$ & $\begin{array}{l}\text { Aberrant modification } \\
\text { TDP- } 43 \text { protein } \\
\text { Mutation in SOD } 1 \text { gene }\end{array}$ & $\begin{array}{l}\text { TDP-43 } \\
\text { Cu/Zn superoxide } \\
\text { dismutase } \\
\text { (SOD1) }\end{array}$ & $\begin{array}{l}\text { Familial: } 50 \\
\text { years } \\
\text { Other: } 60-80 \\
\text { years }\end{array}$ & $\begin{array}{l}\text { Progressive loss of } \\
\text { muscular strength, } \\
\text { muscle cramps }\end{array}$ \\
\hline $\begin{array}{l}\text { Familial } \\
\text { neurohypophyseal } \\
\text { diabetes insipidus } \\
\text { (FNDI) }\end{array}$ & Mutation in AVP gene & Neurophysin II & N/A & Polydipsia, polyuria \\
\hline
\end{tabular}

2016). BJPs can form aggregates like amyloid fibrils and precipitate in tissues. The underlying mechanisms are not fully elucidated, although some mutations have been found to change the aggregation propensity of the proteins (Timchenko and Timchenko, 2018). Clinical features of MM can encompass fatigue, anemia, skeletal pain as well as osteolysis that results in hypercalcemia. One therapeutic strategy includes administration of proteasome inhibitors, which lead to an abundance of misfolded Ig within the mutated plasma cells due to their high production rate, resulting in ER-stress and subsequent apoptosis (Gandolfi et al., 2017).

\subsubsection{Localized Proteinopathies}

Proteinopathies can also manifest in specific cell types and therefore affect only distinct organ systems.

\subsubsection{Non-nervous System-Related Diseases}

A prominent example of a localized non-nervous system-related and age-dependent proteinmisfolding disease is cataract. The crystalline proteins within the eye lens serve to transmit and focus light into a bundle, in order to be projected onto the retina at the back of the eye. During 
aging, different toxic agents accumulate, in particular through UV radiation, oxidation and deamination which make crystalline proteins prone to misfolding and aggregation (Moreau and King, 2012). The protein solution loses its transparency, the lens becomes cloudy and vision is impaired.

\subsubsection{Nervous System-Related Diseases}

An abundance of proteinopathies manifests in the nervous system with increasing age. With little or no ability to regenerate or replace affected cells, the capacity of the nervous system to cope with increasing amounts of misfolded or aggregated species is reached with time leading to disease onset (Cenini et al., 2019).

Alzheimer's disease (AD) is one of the most common age-related neurodegenerative diseases, characterized by progressive cognitive impairment and dementia. Major histological manifestations include senile plaques consisting of pathological forms of the $\mathrm{A} \beta$ peptide in the extracellular matrix and misfolded tau species arranged in intracellular neurofibrillary tangles (NFT) (Lane et al., 2018). A $\beta$ is produced through cleavage of membrane-associated amyloid precursor protein (APP) by $\beta$ - and $\gamma$-secretases. An inadequate clearance of the peptide or mutations in either APP or APP cleaving secretase complexes can trigger accumulation and aggregation of $A \beta$ and amyloid plaque formation (Gouras et al., 2015). Oligomeric $A \beta$ peptides have been found to induce neuroinflammation, mitochondrial dysfunction and oxidative damage, as well as influence synaptic efficacy and kinase/phosphatase activities (Lane et al., 2018). In addition, hyperphosphorylation of microtubule-associated tau protein occurs and results in misfolding and the development of NFT (Iqbal et al., 2009).

Another highly prevalent neurodegenerative disorder is $\mathrm{PD}$, which is predominantly characterized by motor deficits including bradykinesia, muscular rigidity and resting tremor. Pathological hallmarks include the degeneration of dopaminergic neurons in the substantia nigra and intracellular inclusions called Lewy bodies (LB) and Lewy neurites (LN). These formations consist primarily of misfolded or aggregated $\alpha$-synuclein, which is a presynaptic protein considered an IDP (Benskey et al., 2016). Mutations in the SNCA
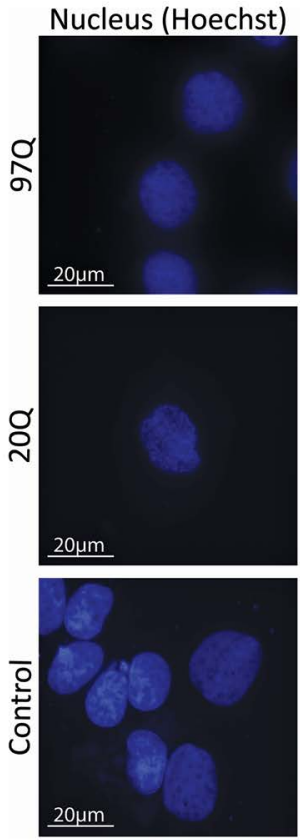
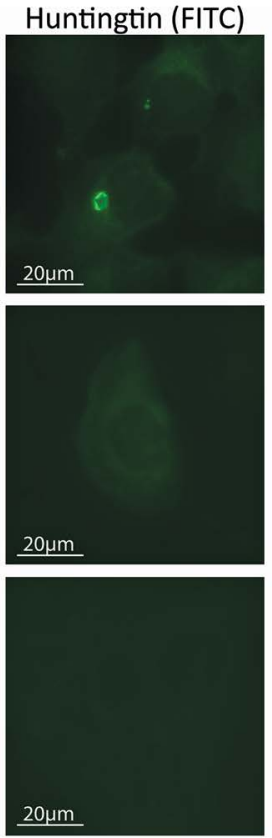
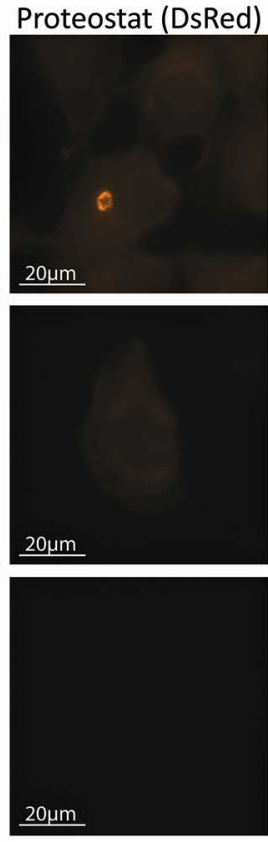
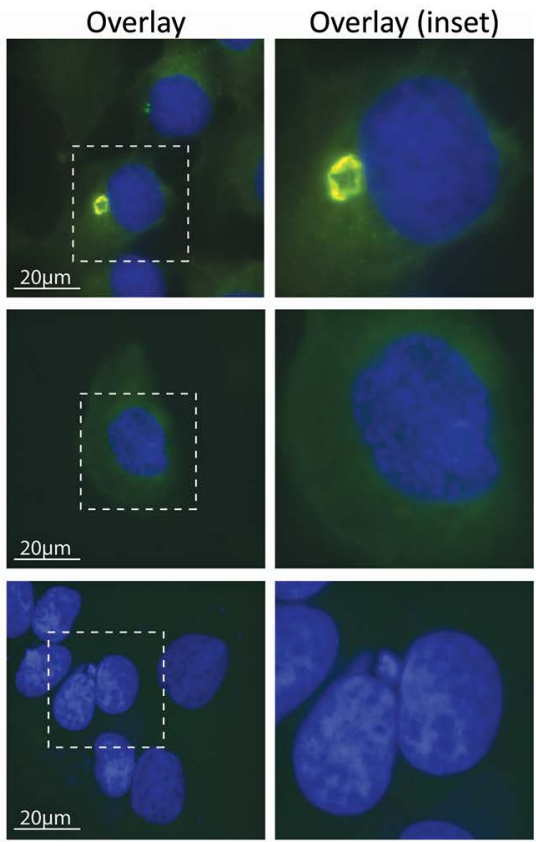

Figure 2.5 Detection of aggregated Htt in human U2OS cells using epifluorescence microscopy. Cells were transfected with HA-tagged exon $1 \mathrm{Htt}$ constructs expressing different polyQ stretch lengths. The cells were stained using an HA antibody (green), Hoechst (blue) and Proteostat (red), a dye that binds aggregates. Cells transfected with the 97Q construct displayed Htt aggregates while the 20Q-transfected cells had an even distribution of HA-tagged Htt without aggregates. 
gene, which encodes for $\alpha$-synuclein, lead to a family of diseases called synucleinopathies (Stefanis, 2012). Synucleinopathy-related toxicity may be caused by impairment of the UPS (Kanaan and Manfredsson, 2012), mechanical damage of cellular compartments due to the involvement of $\alpha$-synuclein in many cellular pathways including synaptic vesicle trafficking and mitochondrial dysfunction (Breydo et al., 2012).

Another late-onset proteinopathy, causing abnormal motor movement, depression, personality change and early death is Huntington's disease (HD). It is the result of a mutation of the HTT gene, leading to the extension of CAG repeats and a consequential expanded polyglutamine (polyQ) stretch in the encoded protein huntingtin $(\mathrm{Htt})$. PolyQ expansions are considered pathological at >35 repeats (Shacham et al., 2019) while the CAG-repeat length determines the age of onset that is between 30 and 50 years. The mechanism underlying neurotoxicity in HD is the misfolding and aggregation of mutated huntingtin due to its polyQ expansion (Figure 2.5).

Amyotrophic lateral sclerosis (ALS) is one of the most common motor neuron diseases in adults. A determining clinical feature is the progressive muscle weakness leading to loss of motor movement and inevitably to respiratory failure (Scotter et al., 2015). The TART-DNA binding protein 43 (TDP-43) shows aberrant modifications in $97 \%$ of ALS cases and can be found aggregated in ubiquitinated inclusions in the brain and spinal cord of ALS, as well as frontotemporal lobar degeneration (FLD) patients (Prasad et al., 2019). In some cases, the superoxide dismutase-1 (SOD1) gene is mutated and leads to SOD1 accumulation in inclusions. Although there is no definite data on how TDP-43 or SOD1 might affect neurotoxicity in ALS, it is suggested that a combination of toxic gain and loss of function might be crucial (Mackenzie et al., 2007).

Prion diseases represent a group of neurodegenerative diseases where protein-only infectious agents cause fatal brain damage. $\mathrm{PrP}^{\mathrm{Sc}}$ are misfolded species that form through conformational changes of the normally folded protein $\mathrm{PrP}^{\mathrm{C}}$ (Collinge, 2016). PrP $\mathrm{P}^{\mathrm{Sc}}$ forms perineural plaques, causing a typical pathological pattern, also known as spongiform encephalopathy. This process is amplified, because $\operatorname{PrP}^{\mathrm{Sc}}$ can cause misfolding and conformational changes in $\mathrm{PrP}^{\mathrm{C}}$ and eventually in other proteins. This so-called templating plays a key role in the prion hypothesis, which suggests that the same processes could underlie the pathological mechanisms of other neurodegenerative diseases (Soto and Pritzkow, 2018). Specifically, it has been hypothesized that misfolded proteins can propagate from cell to cell and initiate templating in neighboring cells (Guo and Lee, 2011).

\subsection{CURRENT AND FUTURE TREATMENTS}

Although there have been many discoveries in the field of age-related proteinopathies, development of efficient therapy strategies has not been entirely successful. Nonetheless, there have been several approaches particularly focusing on modulating PQC systems because of their major role in disease development during aging (Kulka et al., 2020). It is important to note that not only reduction of protein aggregation but also management of toxic oligomeric species should be the target of a therapy (see Table 2.4).

Proteostasis regulators (PRs) are molecules that can interfere with PQC functions and signaling pathways. They can modulate cellular response mechanisms like the cytoplasmic HSR and ER-associated UPR through a number of different mechanisms (Muntau et al., 2014).

Modulation of HSFs has been shown to reduce levels of aggregated proteins and restore proteostasis in several disease models. Non-steroidal anti-inflammatory drugs (NSAIDs), for example, can induce HSF-1 or ensure complete activation of HSR under stress conditions (Jurivich et al., 1992).

Another class of PRs is Hsp90 inhibitors like geldanamycin and its derivatives, which are presently used in cancer therapy. Shifting the conformation of Hsp90 from an ATP-binding to an ADP-binding complex, its chaperone function is inhibited and its association with the UPS is enabled. This leads to disassociation and degradation of Hsp90 client proteins, including steroid receptors, tyrosine kinases and HSF-1, which can initiate the HSR (Sittler et al., 2001).

Proteins that act as sensors of misfolded/ unfolded species and conduct the UPR ${ }^{\mathrm{ER}}$ are the inositol-requiring protein 1 (IRE1), the translation factor 6 (ATF6) and the protein kinase RNA (PKR)-like ER kinase (PERK). ATF6 activates genes involved in protein folding (i.e. ER-associated chaperones), PERK inhibits mRNA translation and IRE-1 upregulates the ERAD pathway and ER-associated chaperones via the X-box-protein 1 
TABLE 2.4

Novel therapeutics in clinical trials affecting protein-misfolding pathologies.

\begin{tabular}{|c|c|c|c|c|c|}
\hline Drug category & Drug/Substance & Phase & Mode of action & Application & References \\
\hline \multirow[t]{3}{*}{ HSP inhibitors } & $\begin{array}{l}\text { 1) XL888 } \\
\text { 2) Vemurafenib }\end{array}$ & $\mathrm{I}$ & $\begin{array}{l}\text { 1) Hsp90 inhibitor } \\
\text { 2) BRAF kinase inhibitor }\end{array}$ & $\begin{array}{l}\text { BRAF-mutated stage III/ } \\
\text { IV melanoma }\end{array}$ & NCT01657591 \\
\hline & Onalespib & I & Hsp90 inhibitor & $\begin{array}{l}\text { Advanced triple } \\
\text { negative breast cancer }\end{array}$ & NCT02474173 \\
\hline & PU-AD & II & $\begin{array}{l}\text { Small molecule epichaperome } \\
\text { inhibitor }\end{array}$ & $\begin{array}{l}\text { ALS } \\
\mathrm{AD}\end{array}$ & $\begin{array}{l}\text { NCT0 } 4505358 \\
\text { NCT04311515 }\end{array}$ \\
\hline $\begin{array}{l}\text { Proteasome } \\
\text { inhibitors }\end{array}$ & Ixazomib & $\mathrm{I} / \mathrm{II}$ & Proteasome inhibitor & Light chain amyloidosis & NCT03236792 \\
\hline $\begin{array}{l}\text { Proteostasis } \\
\text { regulators }\end{array}$ & AMX0035 & II & $\begin{array}{l}\text { Combination: } \\
\text { tauroursodeoxycholic acid } \\
\text { (TUDCA): inhibits ER/ } \\
\text { mitochondrial stress- } \\
\text { mediated apoptosis, reduces } \\
\text { formation of ROS } \\
\text { Sodium phenylbutyrate (PB): } \\
\text { chemical chaperone, histone } \\
\text { deacetylase inhibitor }\end{array}$ & ALS & NCT03488524 \\
\hline NSAID & ALZT-OP1 & III & $\begin{array}{l}\text { Combination: ibuprofen } \\
\text { (NSAID) } \\
\text { Cromolyn (mast cell stabilizer) }\end{array}$ & $\mathrm{AD}$ & NCT02547818 \\
\hline ASO & RG6042 & $\mathrm{I}$ & $\begin{array}{l}\text { Antisense oligonucleotide } \\
\text { (ASO), reduces } \\
\text { concentration of Htt mRNA }\end{array}$ & $\mathrm{HD}$ & NCT04000594 \\
\hline $\begin{array}{l}\text { Small kinetic } \\
\text { stabilizer }\end{array}$ & AG10 & III & Transthyretin stabilizer & $\begin{array}{l}\text { ATTR - cardiomyopathy } \\
\text { Transthyretin amyloid } \\
\text { polyneuropathy } \\
\text { (ATTR-PN) }\end{array}$ & $\begin{array}{l}\text { NCT03860935 } \\
\text { NCT0 } 4418024\end{array}$ \\
\hline \multirow[t]{2}{*}{ Antibodies } & $\begin{array}{l}\text { Lecanemab } \\
\qquad(\text { BAN2401) }\end{array}$ & III & $\begin{array}{l}\text { Monoclonal anti-A } \beta \text { protofibril } \\
\text { antibody }\end{array}$ & $\mathrm{AD}$ & NCT04468659 \\
\hline & PRX004 & $\mathrm{I}$ & $\begin{array}{l}\text { Monoclonal anti-amyloid } \\
\text { transthyretin antibody }\end{array}$ & ATTR & NCT03336580 \\
\hline
\end{tabular}

(Ron and Walter, 2007). Small molecule IRE-1 inhibitors have been discovered to have cytotoxic effects in hematological pathologies. STF-083010, for example, inhibits IRE-1 endonuclease activity and increases the inherent ER stress in MM cells, which translates into cytotoxicity (Papandreou et al., 2011).

Complementing the aforementioned approaches, chemical chaperones can aid to sustain protein stability by broadening the free energy gap between the partially folded and native states of a protein, therefore decreasing the number of unfolded species of aggregation-prone proteins (Hekmatimoghaddam et al., 2017). Additionally, pharmacological chaperones are specific small molecules that can bind to proteins via van der Waals or electrostatic forces and through hydrogen bonds and can facilitate protein folding and trafficking (Beerepoot et al., 2017).

\subsection{CONCLUSIONS}

Protein folding is an essential process in virtually all living systems. It has become clear over the past decade that aging has an adverse effect on protein folding toward the native structure and the capacity of PQC systems, including the system of molecular chaperones. One hypothesis suggests that the decline of crucial PQC components leads to the occurrence of misfolded cellular 
proteins. Therefore, protein-misfolding diseases are likely to be increasing in aging societies. There are many attempts to cure these age-related diseases; however, most of them have failed so far. It is conceivable that the critical time point for disease intervention has already passed when protein misfolding and aggregation occur, and an upregulation of the capacity of PQC systems has to take place far earlier. That means genetic testing has to be increased and the likelihood of a disease onset needs to be determined. Besides ethical considerations, stratification of patients and assessing the individual risk score for a disease needs the establishment of reliable biomarkers or even molecular signatures to initiate personalized treatment.

\section{AUTHOR CONTRIBUTIONS}

Conceptualization, H.O.; writing - original draft preparation, J.-E. R., D.P. and H.O.; writing - review and editing, J.-E. R., D.P. and H.O; visualization J.-E. R. and D.P.; supervision, H.O.; project administration, H.O.; funding acquisition, H.O. All authors have read and agreed to the manuscript.

\section{FUNDING}

This work was funded by the Deutsche Forschungsgemeinschaft (DFG, Germany, RTG 2155, ProMoAge).

\section{ACKNOWLEDGMENT}

The authors acknowledge Thorsten Pfirrmann for critical reading of the manuscript.

\section{CONFLICTS OF INTEREST}

The authors declare no conflict of interest.

\section{REFERENCES}

Anfinsen, C. B. 1973. Principles that govern the folding of protein chains. Science, 181(4096), 223-230.

Anfinsen, C. B., Haber, E., Sela, M., et al. 1961. The kinetics of formation of native ribonuclease during oxidation of the reduced polypeptide chain. Proc Natl Acad Sci U S A, 47, 1309-1314. doi:10.1073/ pnas.47.9.1309

Beerepoot, P., Nazari, R., \& Salahpour, A. 2017. Pharmacological chaperone approaches for rescuing
GPCR mutants: current state, challenges, and screening strategies. Pharmacol Res, 117, 242-251. doi:10.1016/j.phrs.2016.12.036

Benskey, M. J., Perez, R. G., \& Manfredsson, F. P. 2016. The contribution of alpha synuclein to neuronal survival and function - implications for Parkinson's disease. J Neurochem, 137(3), 331-359. doi:10.1111/ jnc. 13570

Benson, M. D., Buxbaum, J. N., Eisenberg, D. S., et al. 2018. Amyloid nomenclature 2018: recommendations by the International Society of Amyloidosis (ISA) nomenclature committee. Amyloid, 25(4), 215-219. doi:10.1080/13506129.2018.1549825

Breydo, L., Wu, J. W., \& Uversky, V. N. 2012. $\alpha$-Synuclein misfolding and Parkinson's disease. Biochim Biophys Acta - Mol Basis Dis, 1822(2), 261-285. doi:10.1016/j.bbadis.2011.10.002

Calderwood, S. K., Murshid, A., \& Prince, T. 2009. The shock of aging: molecular chaperones and the heat shock response in longevity and aging - a mini-review. Gerontology, 55(5), 550-558. doi:10.1159/000225957

Cenini, G., Lloret, A., \& Cascella, R. 2019. Oxidative stress in neurodegenerative diseases: from a mitochondrial point of view. Oxidat Med Cell Longev, 2019, 2105607. doi:10.1155/2019/2105607

Chiti, F., \& Dobson, C. M. 2006. Protein misfolding, functional amyloid, and human disease. Annu Rev Biochem, 75, 333-366. doi:10.1146/annurev. biochem.75.101304.123901

Christianson, J. C., Olzmann, J. A., Shaler, T. A., et al. 2011. Defining human ERAD networks through an integrative mapping strategy. Nat Cell Biol, 14(1), 93-105. doi:10.1038/ncb2383

Clark, P. L. 2004. Protein folding in the cell: reshaping the folding funnel. Trends Biochem Sci, 29(10), 527-534. doi:10.1016/j.tibs.2004.08.008

Cobley, J. N., Fiorello, M. L., \& Bailey, D. M. 2018. 13 Reasons why the brain is susceptible to oxidative stress. Redox Biol, 15, 490-503. doi:10.1016/j. redox.2018.01.008

Collinge, J. 2016. Mammalian prions and their wider relevance in neurodegenerative diseases. Nature, 539(7628), 217-226. doi:10.1038/nature20415

Dill, K. A. 1999. Polymer principles and protein folding. Protein Sci, 8(6), 1166-1180. doi:10.1110/ps.8.6.1166

Dyson, H. J., \& Wright, P. E. 2005. Intrinsically unstructured proteins and their functions. Nat Rev: Mol Cell Biol, 6(3), 197-208. doi:10.1038/nrm1589

Ellis, R. J. 2001. Macromolecular crowding: an important but neglected aspect of the intracellular environment. Curr Opin Struct Biol, 11(1), 114-119. doi:10.1016/s0959-440x(00)00172-x 
Etchells, S. A., \& Hartl, F. U. 2004. The dynamic tunnel. Nat Struct Mol Biol, 11(5), 391-392. doi:10.1038/ nsmb0504-391

Gámez, A., Yuste-Checa, P., Brasil, S., et al. 2018. Protein misfolding diseases: prospects of pharmacological treatment. Clin Genet, 93(3), 450-458. doi:10.1111/cge.13088

Gandolfi, S., Laubach, J. P., Hideshima, T., et al. 2017. The proteasome and proteasome inhibitors in multiple myeloma. Cancer Metastasis Rev, 36(4), 561-584. doi:10.1007/s10555-017-9707-8

Gidalevitz, T., Ben-Zvi, A., Ho, K. H., et al. 2006. Progressive disruption of cellular protein folding in models of polyglutamine diseases. Science, 311(5766), 1471-1474. doi:10.1126/science.1124514

Goor, F. V., Straley, K. S., Cao, D., et al. 2006. Rescue of $\triangle$ F508-CFTR trafficking and gating in human cystic fibrosis airway primary cultures by small molecules. Am J Physiol: Lung Cell Mol Physiol, 290(6), L1117-L1130. doi:10.1152/ajplung.00169.2005

Gouras, G. K., Olsson, T. T., \& Hansson, O. 2015. $\beta$-Amyloid peptides and amyloid plaques in Alzheimer's disease. Neurotherapeutics, 12(1), 3-11. doi:10.1007/s13311-014-0313-y

Gregersen, N., Bross, P., Vang, S., et al. 2006. Protein misfolding and human disease. Annu Rev Genomics Hum Genet, 7, 103-124. doi:10.1146/annurev. genom.7.080505.115737

Guo, J. L., \& Lee, V. M. 2011. Seeding of normal Tau by pathological Tau conformers drives pathogenesis of Alzheimer-like tangles. J Biol Chem, 286(17), 15317-15331. doi:10.1074/jbc.M110.209296

Hartl, F. U. 1996. Molecular chaperones in cellular protein folding. Nature, 381(6583), 571-579. doi: $10.1038 / 381571 \mathrm{a} 0$

Hayer-Hartl, M., Bracher, A., \& Hartl, F. U. 2016. The GroEL-GroES chaperonin machine: a nano-cage for protein folding. Trends Biochem Sci, 41(1), 62-76. doi:10.1016/j.tibs.2015.07.009

Hekmatimoghaddam, S., Zare-Khormizi, M. R., \& Pourrajab, F. 2017. Underlying mechanisms and chemical/biochemical therapeutic approaches to ameliorate protein misfolding neurodegenerative diseases. Biofactors, 43(6), 737-759. doi:10.1002/ biof. 1264

Ignatova, Z., \& Gierasch, L. M. 2006. Inhibition of protein aggregation in vitro and in vivo by a natural osmoprotectant. Proc Natl Acad Sci U S A, 103(36), 13357-13361. doi:10.1073/pnas.0603772103

Iqbal, K., Liu, F., Gong, C.-X., et al. 2009. Mechanisms of tau-induced neurodegeneration. Acta Neuropathol, 118(1), 53-69. doi:10.1007/s00401-009-0486-3
Jurivich, D. A., Sistonen, L., Kroes, R. A., et al. 1992. Effect of sodium salicylate on the human heat shock response. Science, 255(5049), 1243-1245. doi:10.1126/science. 1546322

Kanaan, N. M., \& Manfredsson, F. P. 2012. Loss of functional alpha-synuclein: a toxic event in Parkinson's disease? J Parkinson's Dis, 2(4), 249-267. doi:10.3233/JPD-012138

Kaushik, S., \& Cuervo, A. M. 2012. Chaperonemediated autophagy: a unique way to enter the lysosome world. Trends Cell Biol, 22(8), 407-417. doi:10.1016/j.tcb.2012.05.006

Kendrew, J. C., Bodo, G., Dintzis, H. M., et al. 1958. A three-dimensional model of the myoglobin molecule obtained by x-ray analysis. Nature, 181(4610), 662-666. doi:10.1038/181662a0

Kerner, M. J., Naylor, D. J., Ishihama, Y., et al. 2005. Proteome-wide analysis of chaperonin-dependent protein folding in Escherichia coli. Cell, 122(2), 209-220. doi:10.1016/j.cell.2005.05.028

Knowles, T. P., Vendruscolo, M., \& Dobson, C. M. 2014. The amyloid state and its association with protein misfolding diseases. Nat Rev: Mol Cell Biol, 15(6), 384-396. doi:10.1038/nrm3810

Kulka, L. A. M., Fangmann, P. V., Panfilova, D., et al. 2020. Impact of HDAC inhibitors on protein quality control systems: consequences for precision medicine in malignant disease. Front Cell Dev Biol, 8, 425. doi:10.3389/fcell.2020.00425

Lane, C. A., Hardy, J., \& Schott, J. M. 2018. Alzheimer's disease. Eur J Neurol, 25(1), 59-70. doi:10.1111/ ene.13439

Lashuel, H. A., Petre, B. M., Wall, J., et al. 2002. Alpha-synuclein, especially the Parkinson's diseaseassociated mutants, forms pore-like annular and tubular protofibrils. J Mol Biol, 322(5), 1089-1102. doi:10.1016/s0022-2836(02)00735-0

Levinthal, C. 1969. How to fold graciously. In P. Debrunner, J. C. M. Tsibris, \& E. Münck (Eds.), Proceedings of a Meeting held at Allerton House (pp. 22-24). University of Illinois, Urbana. Curr Opin Struct Biol.

Levy, E., El Banna, N., Baille, D., et al. 2019. Causative links between protein aggregation and oxidative stress: a review. Int J Mol Sci, 20(16). doi:10.3390/ ijms20163896

Liu, Y., \& Eisenberg, D. 2002. 3D domain swapping: as domains continue to swap. Protein Sci, 11(6), 1285-1299. doi:10.1110/ps.0201402

Mackenzie, I. R., Bigio, E. H., Ince, P. G., et al. 2007. Pathological TDP-43 distinguishes sporadic amyotrophic lateral sclerosis from amyotrophic lateral 
sclerosis with SOD1 mutations. Ann Neurol, 61(5), 427-434. doi:10.1002/ana.21147

Mayor, U., Guydosh, N. R., Johnson, C. M., et al. 2003. The complete folding pathway of a protein from nanoseconds to microseconds. Nature, 421(6925), 863-867. doi:10.1038/nature01428

Moreau, K. L., \& King, J. A. 2012. Protein misfolding and aggregation in cataract disease and prospects for prevention. Trends Mol Med, 18(5), 273-282. doi:10.1016/j.molmed.2012.03.005

Muntau, A. C., Leandro, J., Staudigl, M., et al. 2014. Innovative strategies to treat protein misfolding in inborn errors of metabolism: pharmacological chaperones and proteostasis regulators. J Inherit Metab Dis, 37(4), 505-523. doi:10.1007/s10545-0149701-z

New, M., Olzscha, H., Liu, G., et al. 2013. A regulatory circuit that involves HR23B and HDAC6 governs the biological response to HDAC inhibitors. Cell Death Differ, 20(10), 1306-1316. doi:10.1038/cdd.2013.47

Nillegoda, N. B., Kirstein, J., Szlachcic, A., et al. 2015. Crucial HSP70 co-chaperone complex unlocks metazoan protein disaggregation. Nature, 524(7564), 247-251. doi:10.1038/nature14884

Nollen, E. A., \& Morimoto, R. I. 2002. Chaperoning signaling pathways: molecular chaperones as stresssensing 'heat shock' proteins. J Cell Sci, 115(Pt 14), 2809-2816.

Olzscha, H. 2019. Posttranslational modifications and proteinopathies: how guardians of the proteome are defeated. Biol Chem, 400(7), 895-915. doi:10.1515/hsz-2018-0458

Olzscha, H., Fedorov, O., Kessler, B. M., et al. 2017. CBP/p300 bromodomains regulate amyloid-like protein aggregation upon aberrant lysine acetylation. Cell Chem Biol, 24(1), 9-23. doi:10.1016/j. chembiol.2016.11.009

Olzscha, H., Schermann, S. M., Woerner, A. C., et al. 2011. Amyloid-like aggregates sequester numerous metastable proteins with essential cellular functions. Cell, 144(1), 67-78. doi:10.1016/j. cell.2010.11.050

Papandreou, I., Denko, N. C., Olson, M., et al. 2011. Identification of an Irelalpha endonuclease specific inhibitor with cytotoxic activity against human multiple myeloma. Blood, 117(4), 1311-1314. doi:10.1182/blood-2010-08-303099

Pauling, L., Corey, R. B., \& Branson, H. R. 1951. The structure of proteins: two hydrogen-bonded helical configurations of the polypeptide chain. Proc Natl Acad Sci U S A, 37(4), 205-211. doi:10.1073/ pnas.37.4.205
Prasad, A., Bharathi, V., Sivalingam, V., et al. 2019. Molecular mechanisms of TDP-43 misfolding and pathology in amyotrophic lateral sclerosis. Front Mol Neurosci, 12, 25-25. doi:10.3389/fnmol.2019. 00025

Prusiner, S. B. 1982. Novel proteinaceous infectious particles cause scrapie. Science, 216(4542), 136-144. doi:10.1126/science.6801762

Rockenstein, E., Nuber, S., Overk, C. R., et al. 2014. Accumulation of oligomer-prone alpha-synuclein exacerbates synaptic and neuronal degeneration in vivo. Brain, 137(Pt 5), 1496-1513. doi:10.1093/ brain/awu057

Ron, D., \& Walter, P. 2007. Signal integration in the endoplasmic reticulum unfolded protein response. Nat Rev Mol Cell Biol, 8(7), 519-529. doi:10.1038/ nrm2199

Sarge, K. D., Murphy, S. P., \& Morimoto, R. I. 1993. Activation of heat shock gene transcription by heat shock factor 1 involves oligomerization, acquisition of DNA-binding activity, and nuclear localization and can occur in the absence of stress. Mol Cell Biol, 13(3), 1392-1407. doi:10.1128/mcb.13.3.1392

Schapira, A. H., \& Gegg, M. 2011. Mitochondrial contribution to Parkinson's disease pathogenesis. Parkinson's Dis, 2011, 159160. doi:10.4061/2011/159160

Scotter, E. L., Chen, H.-J., \& Shaw, C. E. 2015. TDP-43 proteinopathy and ALS: insights into disease mechanisms and therapeutic targets. Neurotherapeutics, 12(2), 352-363. doi:10.1007/s13311-015-0338-X

Shacham, T., Sharma, N., \& Lederkremer, G. Z. 2019. Protein misfolding and ER stress in Huntington's disease. Front Mol Biosci, 6, 20. doi:10.3389/fmolb. 2019.00020

Shirdel, S. A., \& Khalifeh, K. 2019. Thermodynamics of protein folding: methodology, data analysis and interpretation of data. Eur Biophys J, 48(4), 305-316. doi:10.1007/s00249-019-01362-7

Sittler, A., Lurz, R., Lueder, G., et al. 2001. Geldanamycin activates a heat shock response and inhibits huntingtin aggregation in a cell culture model of Huntington's disease. Hum Mol Genet, 10(12), 1307-1315. doi:10.1093/hmg/10.12.1307

Smith, M. C., Scaglione, K. M., Assimon, V. A., et al. 2013. The E3 ubiquitin ligase CHIP and the molecular chaperone Hsc70 form a dynamic, tethered complex. Biochemistry, 52(32), 5354-5364. doi:10.1021/ bi4009209

Soto, C., \& Pritzkow, S. 2018. Protein misfolding, aggregation, and conformational strains in neurodegenerative diseases. Nat Neurosci, 21(10), 1332-1340. doi:10.1038/s41593-018-0235-9 
Stefanis, L. 2012. Alpha-synuclein in Parkinson's disease. Cold Spring Harb Perspect Med, 2(2), a009399. doi:10.1101/cshperspect.a009399

Stoppini, M., \& Bellotti, V. 2015. Systemic amyloidosis: lessons from beta2-microglobulin. The Journal of biological chemistry, 290(16), 9951-9958. doi:10.1074/ jbc.R115.639799

Timchenko, M. A., \& Timchenko, A. A. 2018. Influence of a single point mutation in the constant domain of the Bence-Jones protein bif on its aggregation properties. Biochemistry (Mosc), 83(2), 107-118. doi:10.1134/S0006297918020037

Umberto, B., Francesca, G., Eleonora, T., et al. 2016. Evaluation of screening method for Bence Jones protein analysis. Clin Chem Lab Med, 54(11), e331-e333. doi:10.1515/cclm-2015-1239
Varela, A. E., England, K. A., \& Cavagnero, S. 2019. Kinetic trapping in protein folding. Protein Eng Des Sel, 32(2), 103-108. doi:10.1093/protein/gzz018

Walter, P., \& Ron, D. 2011. The unfolded protein response: from stress pathway to homeostatic regulation. Science, 334(6059), 1081-1086. doi:10.1126/ science. 1209038

Wang, L., Wang, X., \& Wang, C. C. 2015. Protein disulfide-isomerase, a folding catalyst and a redoxregulated chaperone. Free Radic Biol Med, 83, 305-313. doi:10.1016/j.freeradbiomed.2015.02.007

Xiang, W., Menges, S., Schlachetzki, J. C., et al. 2015. Posttranslational modification and mutation of histidine 50 trigger alpha synuclein aggregation and toxicity. Mol Neurodegener, 10, 8. doi:10.1186/ s13024-015-0004-0 
$\Longrightarrow$ Taylor \& Francis

Taylor \& Francis Group

http://taylorandfrancis.com 